\title{
Feelings and difficulties experienced by cancer patients along the diagnostic and therapeutic itineraries
}

\author{
Sentimentos e dificuldades vivenciadas por pacientes oncológicos ao longo dos itinerários \\ diagnóstico e terapêutico \\ Sentimientos y dificultades vivenciadas por pacientes oncológicos a lo largo de los itinerarios \\ diagnóstico y terapêutico
}

\author{
Elen Ferraz Teston ${ }^{1}$ (1) \\ Eunira Francisca Carvalho Fukumori ${ }^{1}$ \\ Gabriela Michel dos Santos Benedetti ${ }^{1}$ (i) \\ Dandara Novakowski Spigolon ${ }^{1}$ \\ Maria Antônia Ramos Costa ${ }^{1}$ \\ Sonia Silva Marcon² (1D)
}

1. Universidade Estadual do Paraná.

Campus Paranavaí, PR, Brasil.

2. Universidade Estadual de Maringá.

Campus Maringá, PR, Brasil.

\begin{abstract}
Objective: To understand the feelings and difficulties experienced by cancer patients in relation to the diagnostic and therapeutic itineraries. Methods: An exploratory study of a qualitative nature, developed with 13 people with cancer, through an interview. In the period from June to September of 2017 data were collected and later submitted to content analysis. Results: The results included the unpleasant feelings that patients with cancer experience, and the recognition of factors that influence the re-signification of this phase. In addition, we observed the difficulties that perpass the routine of treatment and that compromise the basic needs of these individuals. Final considerations: It was understood that during the experience of the diagnostic and therapeutic itinerary, people with cancer experience negative feelings and many difficulties. However, some factors make possible the resignification of the disease and need to be considered by health professionals and managers to minimize the impact of the disease during this journey.
\end{abstract}

Keywords: Medical Oncology; Nursing; Therapeutics.

\section{Resumo}

Objetivo: Compreender os sentimentos e dificuldades vivenciadas por pacientes oncológicos frente aos itinerários diagnóstico e terapêutico. Métodos: Estudo exploratório, de natureza qualitativa, desenvolvido junto a 13 pessoas com câncer, por meio de entrevista. No período de junho a setembro de 2017 foram coletados os dados e posteriormente submetidos a análise de conteúdo. Resultados: Com os resultados compreendeu-se os sentimentos desagradáveis que os pacientes com câncer vivenciam, e o reconhecimento de fatores que influenciam a ressignificação dessa fase. Além disso observou-se as dificuldades que perpassam a rotina de tratamento e que comprometem as necessidades básicas desses indivíduos. Considerações finais: Compreendeu-se que durante a vivência do itinerário diagnóstico e terapêutico as pessoas com câncer experimentam sentimentos negativos e muitas dificuldades. Entretanto, alguns fatores possibilitam a ressignificação do adoecimento e necessitam ser considerados pelos profissionais de saúde e gestores para minimizar o impacto da doença durante essa jornada.

Palavras-chave: Oncologia; Enfermagem; Terapêutica.

\section{Resumen}

Objetivo: Comprender los sentimientos y dificultades vivenciadas por pacientes oncológicos frente a los itinerarios diagnóstico y terapéutico. Métodos: Estudio exploratorio, de naturaleza cualitativa, desarrollado junto a 13 personas con cáncer, por medio de una entrevista. En el período de junio a septiembre de 2017 fueron recolectados los datos y posteriormente sometidos a análisis de contenido. Resultados: Con los resultados se comprendieron los sentimientos desagradables que los pacientes con cáncer vivencian, y el reconocimiento de factores que influencian la resignificación de esta fase. Además se observaron las dificultades que atravesan la rutina de tratamiento y que comprometen las necesidades básicas de esos individuos. Consideraciones finales: Se comprendió que durante la vivencia del itinerario diagnóstico y terapéutico las personas con cáncer experimentan sentimientos negativos y muchas dificultades. Sin embargo algunos factores posibilitan la resignificación de la enfermedad y necesitan ser considerados por los profesionales de salud y gestores, para minimizar el impacto de la enfermedad durante esa jornada.

Palabras clave: Oncología Médica; Enfermeria; Terapéutica.
Corresponding author:

Elen Ferraz Teston.

E-mail: ferrazteston@gmail.com

Submitted on $01 / 18 / 2018$

Accepted on $07 / 25 / 2018$.

DOI: 10.1590/2177-9465-EAN-2018-0017 


\section{INTRODUCTION}

Among public health issues, cancer due to it's epidemiological amplitude, is one of the most complex ones. It's orign can be attributed to envirornmental, behavioral and hereditary factors. ${ }^{1}$ In 2015, cancer was responsible for 8,8 million deaths, constituting the second most frequent cause of death in the world. ${ }^{2}$ In Brazil, in that same year, cancer was responsible for the death of 223,4 thousand people. Estimates point out the occurance of 600 thousand cases of this illness during the years of 2018 and $2019 .{ }^{3}$

Facing this scenario we highligh the relevance of this thematic due to high rates of population morbimortality and by the need of organizing health services network to offer actions of prevention, promotion, diagnosis, reabilitation and palliative care. ${ }^{4}$

This way, the National Policy for Prevention and Control of Cancer preconizes that caring to the person with cancer should contemplate different attention points in Health Network in order to guarantee access and integral care. And for such, care is organized considering the stabilishment of reference and counterreference flux between primary care, which constitutes as the entrance door for the health system user, and medium and high complexity services. ${ }^{4}$

It's understood that, from what we stated, for access and health care quality for people suffering from this illness, various aspects must be considered from the diagnosis until the deffinition of treatment modality. Therefore, these aspects involve the course in the different points of attention, living experiences and unchained movements - concerning a succession of events - and making decisions that influenced the illness. ${ }^{5,6}$

In this perspective, it's denominated diagnostic itinerary the pathway traveled through the network, since the emergence of the first signs and symptoms until the definition of the cancer diagnosis. ${ }^{7}$ The therapeutic itinerary refers to the care journey that comprehenses all actions related to access to health services, professional services, family and other support networks. ${ }^{8}$ This itinerary may also be the pathway traveled by the individual in three different levels of health services attention seeking care, evidencing behaviors and conceptions that may support the implementation of care qualification actions to this public. ${ }^{8}$

We highlight the technological progress of ways of diagnosis and therapeutic procedures amplified the patients' survival, taking health professionals to worry with reabilitation/treatment ways and with the planning of actions and interventions that can improve quality of life, throughout the whole process of care. ${ }^{9}$ This way, to effectiveness of this process it's necessary not only to know the itinerary traveled by patients buy also the feelings unveiled through them.

Even though it's recognized inumerous efforts to strenghten the oncological care network, there are weaknesses that can be triggered by geographical, economical and social barriers. In this sense, it's important the planning of strategies that enable access in an opportune time and that guarantee integral and continous care, that reflect directly in adherence of the proposed treatment. ${ }^{10}$

Thus, to the above-mentioned, supported the present study in the following question: how does the person with cancer experience diagnositic and therapeutic itinerary?

To comprehend how these itineraries are lived and feelings are experienced enables the recognition of a series of detailed events and attitutes to mantaing life, ${ }^{11}$ and also of inumerous human dimensions that comprehend knowledge and forms to experience the illness, which contributes to elaborating a health care consistent to the reality of people with cancer. ${ }^{12}$

Facing this, the present study aimed to comprehend feelings and difficulties experienced by oncological patients facing diagnostic and therapeutic itinerary.

\section{METHOD}

Exploratory study, of qualitative nature, developed with patients in treatment for cancer registered in the Association of People with Special Diseases (APSD) of a municipality in the northwest region of Paraná, which had 81.590 inhabitants in the last Censo and it's the home of one of the 22 Health Regionals of Paraná which aggregates 20 munipalities. In the health area, caring for people with cancer, in this municipality, for study occasion, had 17 Primary Health Care Units, all with Family Strategy Teams (total of 24 teams); City Emergency Care; a private hospital with an agreement with the Unique Health System, with 172 beds; a Specialities Regional Center; Integrated Health Care System; and a Mobile Health Unit. It didn't have, thus, a specialized oncological care service. People that needed/need treatment were/are referentiated to a bigger city and headquarters of another Health Regional, far for about 75 kilometers.

APSD, for once, is a philantropic organization, mantained by donation and finantial resources from the city;s Social Assistance Ministry. It aims to help people with cancer in social vulnerability situation, distributting freely medications, diapers and basic baskets, developing loans of hospital equipment (bed, wheelchair, bath chair, mattress, water mattress, among others), it offers emotional support and health to book and/or expedite consultations, exams, specialized treatments, and daily makes the transportation of patients for the city they need treatment outside where they life.

This study's participants were selected through the following inclusion criteria: age equal or over 18 years old; being in oncological treatment for at least two months and know the diagnosis. For once, people with communication limitations or impairments that unable comprehension during the interview were excluded.

Initial contact with participants happened through telephone, from patient's contact list from APSD. In this contact, they were informed about the study and invited to participate on it. If accepted it, a home visit was scheduled. 
In the period from June to Spetember 2017, interviews were developed individually and reorded, from the following guiding question: Talk about your journey from the first signs of health alteration. Seeking information occurred until the moment the data started to become repetitive and when we considered to reach the research's aim. ${ }^{13}$

Interviews were transcribed fully, preferrably in the same day they were developed and submitted to content analysis, themathic module, following the steps: pre-analysis (reading speeches and highlighting key points); material exploitation, highlighting results and interpretation, originating themathic categories. ${ }^{14}$

This research was approved by the Research Ethics Commitee, with CAAE no 68771017.6.0000.0104, Feedback no 2.403.152, in observance to ethical aspects prescribed in the Resolution no 466, from December 12 2012, from National Council of Health. Participants were identified by the letters $P$, and $M$ and $F$ indicating Male and Female, followed by age and type of cancer (PF34BREAST).

\section{RESULTS}

\section{Participants' characterization}

The 13 participants of this study were between 34 and 78 years old, being most of them female. On Table 1 sociodemographical characteristics, type of cancer and treatment they were submitted are observed.

From qualitative data analysis emerged two themathic categories described in the following.

\section{From the perception of alteration in the begining of treatment: feelings and difficulties experienced}

In this category, we included reports that showed from the begining, with the perception of health alterations, people experienced fear and sadness, specially for the fact they associated cancer with suffering and death.

I discovered the breast cancer making a routine examination in a private clinic, but then it came with alteration so I went to the primary care to ask for a referral to do the treatment. They referred me to surgery and then I started radio and chemo [...] In the begining, I was very scared because I already knew I would have to take the whole breast out and that the treatment would be painful and long [...]I was scared of nothing working out. (PF34BREAST).

My cancer was the following: I was making a routine examination in the primary care, then it showed an a problem in my urinary system, I went to the specialist and then they sent me to APSD that forwarded my referral to the Cancer hospital... then I started treatment. As I knew, in the primary care consultation, I was frightened, because news like this, the first thing that comes to mind is the end
Meu câncer foi o seguinte: estava fazendo exame de rotina no postinho, ai apresentou um (PM64PROSTATE).

It was very difficult in the begining I thought I was going to die, it was sadness [...] / cried a whole day (PF45BREAST)

The discovery happened making a mammography exam, the doctor in the primary care was directed about what it was. I knew in the end of 2012 and had surgery in 2013, I took the whole breast out. [...] They sent me to CRE for a specialist. Then my daughter sought APSD with the referral and I started treatment at the cancer hospital [...] it's a mixture of fear of dying and fear of becoming dependent [...] (PF64BREAST)

In this journey, the flux and communication in the network showed themselves to be fragile. The waiting time between the definition of a diagnosis and the decision of the type of treatment generated angst and expecation due to incertainties and unfamiliarity in the next steps to be given:

That thing that the exam comes with an alteration and until you do the treatment is very bad [...] it's a very long pathway and leaves us uncertain of what's going to be. I did the mammography first, then they sent me to reference center and then I went to Maringá and there I started treatment (PF4OBREAST).

With treatment initiated, participants revealed that absence of a family member/companion in the places treatments were developed awakened loneliness and increased insecurity facing the illness:

Having this illness is not easy and feeling alone is even worst [...] My daughter works then she couldn't be with me there [...] She had her obligations. [...] (PM53RETUM).

The feeling of not having anyone with you is very bad, so I had to go to the Cancer Hospital get chemotherapy alone [...] it was I go or I go [...] there was no other option. It was an emptiness I can't explain (PF49BREAST).

However, some participants took the time they remained in reference health services, waiting to be seen, to know other people who lived in the same conidtion, which, in some form, helped them to face the context of sickening in this pathway.

[...] I stood talking to people that did the treatment with me, it passed the time, I made friends (PM 78PROSTRATE).

I met many people and made friends in this treatment journey. This made time go by faster (PF44INTESTINE). 
Table 1. Sociodemographical characteristics, type of cancer and treatment

\begin{tabular}{|c|c|c|c|c|c|c|c|}
\hline Gender & Age & Education & $\begin{array}{l}\text { Family } \\
\text { income* }\end{array}$ & $\begin{array}{c}\text { Civil } \\
\text { status }\end{array}$ & Occupation & $\begin{array}{l}\text { Type of } \\
\text { cancer }\end{array}$ & Type of treatment \\
\hline Female & 34 & $\begin{array}{l}\text { High school } \\
\text { completed }\end{array}$ & Doesn't know & Separated & Housewife & Breast & $\begin{array}{l}\text { Surgery and } \\
\text { chemotherapy }\end{array}$ \\
\hline Male & 64 & $\begin{array}{l}\text { Elementary School } \\
\text { incompleted }\end{array}$ & 1 to 2 & Married & Retired & Prostrate & radiotherapy \\
\hline Male & 78 & $\begin{array}{l}\text { Elementary School } \\
\text { incompleted }\end{array}$ & 1 & Married & Retired & Prostate & Radiotherapy \\
\hline Female & 40 & $\begin{array}{l}\text { High school } \\
\text { completed }\end{array}$ & 2 to 3 & Married & $\begin{array}{l}\text { Gas station } \\
\text { manager }\end{array}$ & Breast & Chemotherapy \\
\hline Female & 49 & $\begin{array}{l}\text { High School } \\
\text { completed }\end{array}$ & 3 & Married & $\begin{array}{c}\text { Public } \\
\text { employee }\end{array}$ & Breast & Chemotherapy \\
\hline Female & 78 & $\begin{array}{c}\text { Elementary School } \\
\text { incompleted }\end{array}$ & 2 & Married & Seamstress & Uterus & $\begin{array}{c}\text { Surgery and } \\
\text { chemotherapy }\end{array}$ \\
\hline Female & 64 & $\begin{array}{l}\text { High school } \\
\text { incompleted }\end{array}$ & 1 & Divorced & Hoursewife & Breast & $\begin{array}{c}\text { Surgery, chemotherapy } \\
\text { and radiotherapy }\end{array}$ \\
\hline Male & 58 & $\begin{array}{l}\text { High School } \\
\text { completed }\end{array}$ & 4 & Married & Merchant & Prostrate & Radiotherapy \\
\hline
\end{tabular}

* In minimum wage from Brazil (R\$ 937,00), year 2018.

Some participants reported that feelings of hope and strength to fight against the illness emerged on coexisting with other patients in places of treatment and observing the condition of them.

When I stayed there in the cancer hospital waiting I kept thinking how it would be from now on, if I was going to die, if my hair would fall, it was very difficult. But then I saw people worst than me, I saw people very sick. So I started to feel stronger to fight the illness. I realized I still had strength to fight, I wasn't so weak (PF64BREAST).

I saw many things while I waited to do chemotherapy, so much suffering [...] people missing pieces and I thought: How thankful I am to be here fully, fighting against something that is only on the inside [...] and then it charged my strengths to the next o (PM78PROSTATE).
The support offered by the social network was also highlighted as a signal of love and care, which minimized the feeling of loneliness presented in this journey many times:

One day in the church's cult, when I was still without hair, only a scarf, I received a surprised. The pastor and the church's sister prepared a beautiful homenage to me. When I arrived in the church, all sister had a scarf of their head. One prettier than the other. I knew I wasn't alone. They were all praying to God for me. In this day the pastor preached about "gesture of loving the other. It was beautifu!! (PF52BREAST).

In a more specific mode, the faith was referred as source of strength and motivation that sustained patients in sickening rails and treatment. 
[...] When I was in my moments of prayer at home and, on my knees crying desperate, God talked to me. And he told me: "Daughter, I already knew you in your mother's belly, you didn't have hair, didn't walk nor talk and I already loved you". And this fed me with new strengths each day (PF78UTERUS).

After asking God a lot, there was an evening alone in my room that I said, now I won't cry anymore, if I have to go through this, let it be the best way possible and what God has for me I have to accept it. Then I started to focus on putting in my head that I have to be well to go through all this [...] and it was like this that God helped to go through it all [...] I never felt sick in any period of treatment (PF44INTESTINE).

Thus, during diagnosis and therapeutic itinerary, the person with cancer experiences inumerous unpleasant feelings, however, in meeting people that experience the same reality with others that extend the hand, giving support, and with faith, emerges the possibility of resignification of his/her experience with the illness.

\section{Difficulties experienced throughout the therapeutic itinerary}

For some interviewees, the side effects manifested after the chemo and radiotherapy sessions were constituted in one of the main difficulties after the begining of treatment:

[...] I felt bad after two days of chemo, I was feeling bad, nothing stayed in my stomach, it was the worst part, what made me give up the treatment many times. Today this is very more and less, I don't know if it's because I'm used to it or because it's weaker (PF34BREAST).

Ahh [...] the toughest part are the chemo side effects, because each session is different than the other. The first you feel bad, the second is worse [...] then comes depression, hair falling [...] it's a lot [...] a lot (PF40BREAST).

Aside from not being able to eat and getting very nauseous I was all burned, because the radio burns from the inside out. There were days that even the blouse that you wash again hurt because it burned and it was all flesh (PF45BREAST).

Other difficulties pointed out were tiredness and disconforts due to transfer between their homes to the place where they did the treatment.

To do the treatment we have to drive $60 \mathrm{~km}$, it's tiredsome, and I can't sleep in the van because I'm afraid of having an accident, this things. And even after some sessions of radio I had burns that was weird to sit (PM58PROSTRATE).
It's a trip each session[...] we enter the car debilitated, week, nauseous specially those who did chemo [...] (PM53RETUM).

Waiting time to return to home is also tiring, because in a same vehicle many patients are transfered, with different times scheduled:

After we do chemo, we have to wait other patients finish to go home. We leave at $5 \mathrm{AM}$ and get back at 18h. For those who are well and can handle standing [...] now for those who are not so well [...] (PM64PROSTRATE).

The most difficult is the waiting [...]there are too many people to do at the same time, so it's one at a time [...] and each one is scheduled at a different time, different medication, different time to receive it. This makes us irritated, sad and stressed with life (PF34BREAST).

It's very tiring to be there waiting everyone to be done to go home [...] it makes us even more tired (PM53RETUM).

Lastly, some made reference to the issue of feeding after treatment with a difficulty due to the time they stay outside the house and finantial conditions. However, they also said this difficulty is also minimized by the voluntary action:

We left very early so we didn't eat anything, but we were lucky to arrive there and have people donating breakfast [...] lunch. People who have done treatment there do this job to help those who need [...] People that also did treatment there in the cancer hospital and also people who made a promise to distribute breakfast (coffee, warm milk and bread or cake) and lunch for us, this help us a lot to not be fasting (PF4OBREAST).

Our luck was that lunch people served there [...] because to be the whole day without eating anything it's not possible [...] and money to take to buy food there is not possible [...] there are many days [...] (PM64PROSTATE).

It's verified, this, that the oncological patient during the therapeutic ininerary experience difficulties that go through the needed treatment routine and commit significally on assessing basic needs- sleep and feeding -, which results in feeling bad during this journey.

\section{DISCUSSION}

With the focus on the individual that experiences illness, therapeutic itinerary offers the opportunity to elucidate compositions of meanings, attitudes and feelings constructed throughout this sickening journey. ${ }^{8}$ The present study evidences feelings experiened by people who traveled hard pathways 
until they received the diagnosis for cancer and having their treatments defined, experienced many difficulties throughout the treatment journey.

The prevalence of negative feelings is due to, mainly, the great challenge that this illness represents for individuals, their families and professionals. And for affecting greatly the physical and psychosocial well being ${ }^{15}$ from the perception of the first signs and symptoms until the moment of the diagnosis and begining of treatment, great changes are due to the life of patient and family, emerging questions directed to life, disease and death, as statements from PM64PROSTATE, PF45BREAST and PF34BREAST. Negative feelings are unleashed and aggravated fom the unfamiliarity of the sick individual and his family about different network points to the oncological patient and the function of each of them. ${ }^{16}$

Even though participants' speeches showed the existence of an organized care network to the oncological patient, there are weaknesses on the flux and communication between health services and users. A study developed in Rio de Janeiro, which mapped the itinerary of the oncological patient- do diagnosis to treatment -, pointed out that these users experience lack of clarification on illnesses, prognostic treatment, what doesn't enable them to participate in therapeutic decisions. ${ }^{9}$

In this sense, it's highlighted the importance of initial welcoming to the patient, from the emergence of the first complaints about the perception of alteration of health state or the emergence of signs and symptoms, and specially by diagnosis occasion, in order to clarify doubts and direct them adequately close to the attention point. Professionals may also inform themselves, guide and discuss with the patient different possibilities and steps of oncological treatment. ${ }^{10}$ Health team, specially Primary Care, can have an important role in this context, because bond, when preexisting or already stabilished after diagnosis, favours therapeutic communication, which, for once, enables facing sickening journey and treatment and soften the psychological load the individual experiences with his family members. ${ }^{17}$

It's highlighted that noise from mistaken or insufficient communication, characterized by incomplete informations, with low resolutiveness and that doesn't clarifysteps and different points of care that compose the care and treatment network to be instuted, aggravate fear and anxiety to the unknown. However, the stabilishment of process of effective communication enables the health professional to know and interpret people's attitudes mediated the experience of sickening and, thus to guide the decision making process faceing the care needs. ${ }^{18}$

Negative feelings and thoughts also become evident during the treatment course- independent of the type -, because, beyond impacting quality of life they also influence adherence of the same. Study that used psychological assistance with oncological patients, during chemotherapy, pointed that experienced angst during treatment can exacerbate emotional suffering of those who are already week and vulnerable facing the diagnosis. ${ }^{19}$ This way, the follow up during treatment by the Family Health team, through home visits, for exemple, constitutes a strategy that enables the patient to share experiences and feelings on different steps of therapeutic itinerary. It's believed that this care, when exercised by a multiprofessional team, can contribute to soften negative feelings and clarify doubts related to the whole process.

In turn, the family is also considered an effective resource for coping with the disease by the patient, playing an essential role in helping basic cancer care and emotional support, favoring the emergence of feelings of safety and solidarity. ${ }^{20}$ The spouse or partner, among the relatives, is responsible for offering $94.3 \%$ of social support in coping with the disease. ${ }^{21}$

In the present study, it was observed the absence of family member/companion, throughout the therapeutic itinerary developed in another city, contributed to aggravate patient's insecurity, as verified in speeches by PM53RECTUM and PF49BREAST. Thus, the need for health professionals to use strategies to strengthen the family bond, in order to provide and facilitate the search for intra-family support, although it is difficult to experience the patient's fragility in the face of illness. ${ }^{15}$

It's worth to highlight that, facing family absence from health services, coexisting and exchanging experiences with other people who experienced the same sickening condition unleashed feelings of hope and strength to fight against the illness. In this sense, a korean study pointed out the strength of social network of cancer patients, through developing of group meetings, favoured coping with the illness and imporved their quality of life because individuals generate support through sharing their experiences, difficulties and strategies used to coping with them. ${ }^{22}$

Organizing educational activities with groups of patients and family members was also suggested by a spanish study, in order to identify early different issues and concerns that can emeerge througout the treatment. It's an effective initiative to give specific guidance, enabling sharing experiences and concerns among equals, as they receive suggestions that can assist them to face the process. ${ }^{23}$

In the same way, sources of support, love and care, during the course of treatment can be found on friendship relationships and group experience, such as religous, for exemple, as pointed out by PF52BREAST. It stands out the religiosity as a predominant factor in the perception of the participants, this because, faced with the difficulties experienced during this trajectory, individuals tend to find relief and comfort in the faith. In this sense, support groups must be stimulated by the health team, and partnerships can be stabilished with members of the church. A review study pointed out that health education programs on fighting cancer developed in partnership with the church produced a positive impact. ${ }^{24}$

Among difficulties experienced throughout the therapeutic itinerary, side effects were manifested: tiredness produced by 
the transfer to treatment development; the long waits to return home; the feeding need during the period they are outside of the hosue for treatment, and lack of finantial condition to finance it; rotuine alteration by the constant need of being present in health services and the continuous exposion to invasive procedures.

These fidings are corroborated by a study developed in Colombia, which points out that patients, beyond lack of information, face problems related to the health system, economical, political, geographical issues, issues related to social support network and family, ${ }^{25}$ which makes sick people still more weak and vulnerable. ${ }^{19}$

Vulnerability, in turn, can lead to denial of the disease, compromising adherence to the proposed treatment.. Knowledge, from health professionals, of feelings experienced by patients, throughout diagnosis and therapeutic itinerary, enables welcoming angst and suffering, and also the development of actions of health education, which can influence adherence of self care actions and to treatment. ${ }^{26} \mathrm{It}$ 's important to highlight that physical and psychological needs of cancer patients must be treated accordingly through continuous care. Their demands must be met in all phases of the disease. ${ }^{23}$

In order to perform the treatment, many patients need to move to a reference municipality, due to the conformation of the care network and, mainly, the high costs represented by the different types of treatment and its complexity. Although the right to transportation, food and daily allowance for cancer patients and their companion through the Unified Health System, ${ }^{5}$ in practice this right is summarized to transport. It is worth mentioning that the way patients experience this course has a direct impact on their well-being and quality of life.

The condition of illness, such as cancer, also compromises financial power, especially if the patient is the provider of the family. A study carried out with 22 patients on chemotherapy indicated that they are sometimes the main responsible for the maintenance of the house, and that the necessity of accomplishment prevented this from continuing. ${ }^{27}$

Thus, even though patients have a few rights guaranteed by Law, they still have diverse spences due to treatment/illness, for exemple, the need to feed themselves while they wait the return to the city of origin, after treatment. It's highlighted that this need is bypassed by the support of volunteers that distribute breatfast and lunch.

It must be considered that the difficulties faced by patients are the result of a series of structural barriers that require reforms in the health system. ${ }^{25}$ Thus, we reiterate the need to rethink the logistics of patient displacement, as well as other problems experienced, in order to alleviate the difficulties experienced for the treatment.

It should be emphasized that the responsibility of the municipalities to the patients who need to perform specialized treatment outside the home involves more than the transportation to the reference municipality. Managers, in addition to considering the fragility conditions mentioned, should also be aware of the implications for the health and well-being of these patients when they remain a whole day (dawn at night) without a place to rest and without adequate food.

\section{FINAL CONSIDERATIONS}

From the understanding of the experiences of the participants of the study, it is possible to point out that the diagnostic and therapeutic itineraries are marked by fragilities of the network of attention to the oncologic patient and by negative feelings of the patient, most of the time due to the association of the disease with the death. Anxiety and insecurity are aggravated by the lack of knowledge about the functioning of the health care network and the lack of follow-up of family members during treatment. However, the social support network, coexistence with other people in the same situation of illness and religiosity are sources of strength and motivation to face this journey of illness and treatment.

Discourses also revealed the main difficulties experienced throughout therapeutic itinerary, highlighting side effects of antineoplastic therapy, fatigue triggered by the displacement to another municipality, need for food and lack of financial resources to pay for it.

The present study advances in order to elucidate new challenges to the different points of health care, aiming to assure the patient a humanized and integral treatment, so that he feels welcome to share his anxieties and doubts regarding the diagnostic and therapeutic itineraries. Beyond that, it's highlighted the need to stabilish ne strategies to soften evidenced difficulties. As study limitation there is: difficulty in establishing a sufficient link with the interviewees - due to the short time of contact -, in order to enable the verbalization of other experiences that may have been omitted; the fact that diagnosis time was not considered as inclusion criterion, considering that it may influence the different experiences experienced by the participants.

\section{REFERENCES}

1. Ministério da Saúde (BR). Instituto Nacional do Câncer José Alencar Gomes da Silva. Coordenação Geral de Ações Estratégicas. Coordenação de Educação ABC do Câncer: Abordagens Básicas para o Controle do Câncer. $2^{\mathrm{a}}$ ed. Rio de Janeiro (RJ); 2012 [Internet] [cited 2018 Jan 12]. 129 p. Available from: http://bvsms.saude.gov.br/ bvs/publicacoes/inca/abc_do_cancer_2ed.pdf

2. World Health Organization (WHO). Early cancer diagnosis saves lives cuts treatment costs. 2017 [Internet]. [cited 2018 Apr 4]. Available from http://www.who.int/mediacentre/news/releases/2017/early-cancercosts/en/

3. Ministério da Saúde (BR). Instituto Nacional do Câncer José Alencar Gomes da Silva. Estimativa 2018: Incidência de Câncer no Brasil. Brasília (FD): Ministério da Saúde; 2018 [Internet]. [cited 2018 Apr 4] Available from: http://www.inca.gov.br/estimativa/2018/introducao.asp

4. Simino GPR, Santos CB, Mishima SM. Acompanhamento de usuários portadores de câncer, por trabalhadores da saúde da família. Rev Latino Am Enferm [Internet]. 2010 Set/Oct; [cited 2017 Aug 22]; 18(5):1-9. Available from: http://www.scielo.br/pdf/rlae/v18n5/pt_04.pdf 
5. Ministério da Saúde (BR). Portaria № 874/2013, de 16 de maio 2013. Institui a Política Nacional para a Prevenção e Controle do Câncer na Rede de Atenção à Saúde das Pessoas com Doenças Crônicas no âmbito do Sistema Único de Saúde (SUS). Brasília (DF): Diário Oficial da União [Internet]. [cited 2018 Jan 12]. Available from: http://bvsms. saude.gov.br/bvs/saudelegis/gm/2013/prt0874_16_05_2013.html

6. Cabral ALLV, Martinéz-Hemáez A, Andrade EIG, Cherchiglia ML. Itinerários terapêuticos: o estado da arte da produção científica no Brasil. Ciênc Saúde Coletiva [Internet]. 2011; [cited 2018 Apr 4]; 16(11):4433-42. Available from: http://www.scielo.br/pdf/csc/v16n11/ a16v16n11.pdf

7. Vidotto PCP, Ferrari RAP, Tacla MTGM, Facio BC. Maternal experience in the diagnostic itinerary of child cancer. Rev Enferm UFPE On Line [Internet]. 2017 Apr; [cited 2018 Mar 31]; 11(4):1565-73. Available from: https://periodicos.ufpe.br/revistas/revistaenfermagem/article/ view/15224/17985

8. Soares DA, Santos EM, Arruda IS. Itinerários terapêuticos de pessoas com câncer: produção científica no Brasil. Rev APS [Internet]. 2017 Jan/ Mar; [cited 2018 Mar 31];20(1):118-29. Available from: https://aps.ufjf. emnuvens.com.br/aps/article/view/2881/1074

9. Souza KZ, Souza SR, Tocantins FR, Freitas TF, Pacheco PQC. O itinerário terapêutico do paciente em tratamento oncológico: implicações para a prática de enfermagem. Cienc Cuid Saúde [Internet]. 2016 Apr/Jun; [cited 2017 Aug 22]; 15(2):259-67. Available from: http://eduem.uem.br/ojs/index.php/CiencCuidSaude/article/ view/29896/17399

10. Aquino RCA, Vilela MBR. Comunicação dos pacientes com câncer: preocupação relacionada ao tempo de espera para o acesso e o itinerário terapêutico aos cuidados oncológicos. Distúrb Comum [Internet]. 2014 Jun; [cited 2017 Aug 22]; 26(2):420-2. Available from https://revistas.pucsp.br/index.php/dic/article/viewFile/17757/14657

11. Silva TMR, Souza SR, Couto LL. Itinerário terapêutico de adolescentes com osteossarcoma: implicações para o diagnóstico precoce. REME Rev Min Enferm [Internet]. 2017; [cited 2018 Mar 31]; 21:e-1028. Available from: http://www.reme.org.br/artigo/detalhes/1164

12. Silva DC, Budó MLD, Schimith MD, Rizzatti SJS, Simon BS, Robaina ML. Itinerário Terapêutico: tendência em teses e dissertações da enfermagem. Saúde (Santa Maria) [Internet]. 2014 Jan/Jul; [cited 2017 Dec 27]; 40(1):23-32. Available from: https://periodicos.ufsm.br/index. php/revistasaude/article/viewFile/9097/pdf_1

13. Pires AP. Amostragem e pesquisa qualitativa: ensaio teórico e metodológico. In: Poupart J, Deslauriers JP, Groulx LH, Lapemère A, Mayer R, Pires AP, orgs. A pesquisa qualitativa: enfoques epistemológicos e metodológicos. Petrópolis: Editora Vozes; 2008. p. 154-211.

14. Bardin L. Análise de conteúdo. Tradução de Luís Antero Reto e Augusto Pinheiro. São Paulo: Edições 70; 2011.

15. Haun MW, Estel S, Rücker G, Friederich HC, Villalobos M, Thomas $M$, et al. Early palliative care for adults with advanced cancer. Cochrane Database Syst Rev [Internet]. 2017 Jun; [cited 2017 Dec 27]; 12;6:CD011129. Available from: https://www.ncbi.nlm.nih.gov/ pubmed/28603881

16. Brustolin A, Ferretti F. Itinerário terapêutico de idosos sobreviventes ao câncer. Acta Paul Enferm [Internet]. 2017; [cited 2017 Dec 27]; 30(1):47-59. Available from: http://www.scielo.br/pdf/ape/v30n1/1982 0194-ape-30-01-0047.pdf
17. Matoso LML, Rosário SSD, Matoso MBL. As estratégias de cuidados para o alívio dos efeitos colaterais da quimioterapia em mulheres. Saúde (Santa Maria) [Internet]. 2015 Jul/Dec; [cited 2017 Dec 27]; 41(2):251-60. Available from: https://periodicos.ufsm.br/index.php/ revistasaude/article/viewFile/10883/pdf

18. Rennó CS, Campos CJ. Interpersonal communication research valorization of the oncological patient in a high complexity oncology unit. REME Rev Min Enferm [Internet]. 2014 Jan/Mar; [cited 2017 Dec 27]; 18(1):116-25. Available from: http://www.reme.org.br/artigo/ detalhes/912

19. Sette CP, Gradvohl SMO. Vivências emocionais de pacientes oncológicos submetidos à quimioterapia. Rev Psicol UNESP [Internet] 2014; [cited 2017 Dec 27]; 13(2):26-31. Available from: http://pepsic. bvsalud.org/pdf/revpsico/v13n2/a03.pdf

20. Vestena Zillmer JG, Schwartz E, Burille A, Linck CL, Lange C, Eslabão A. Vínculos de los clientes oncológicos y familiares: una dimensión para ser observada. Enferm Glob [Internet]. 2012 Jan; [cited 2017 Dec 27]; 25:45-52. Available from: http://scielo.isciii.es/pdf/eg/v11n25/ pt_clinica3.pdf

21. Salakari M, Pylkkänen L, Sillanmäki L, Nurminen R, Rautava $P$ Koskenvuo M, et al. Social support and breast cancer: a comparatory study of breast cancer survivors, women with mental depression, women with hypertension and healthy female controls. Breast [Internet] 2017 Oct; [cited 2017 Dec 27]; 35:85-90. Available from: http://www. thebreastonline.com/article/S0960-9776(17)30489-7/fulltext

22. Kim MA, Yi J, Prince KC, Nagelhout E, WuYp. The Effects of Individualand network-Level factors on discussion of cancer experiences: survivors of childhood cancer in Korea. J Psychosoc Oncol [Internet]. 2018; [cited 2018 Jan 2]; 36(1):31-48. Available from: http://www. tandfonline.com/doi/abs/10.1080/07347332.2017.1379582?journal Code $=$ wjpo20

23. Vila $C$, Reñones $C$, Ferro T, Peñuelas MÁ, del Mar Jiménez $M$, Rodríguez-Lescure Á, et al. Advanced breast cancer clinical nursing curriculum: review and recommendations. Clin Transl Oncol [Internet] 2017 Aug; [cited 2017 Dec 27]; 19(2):251-60. Available from: https:// www.ncbi.nlm.nih.gov/pmc/articles/PMC5239810/

24. Hou SI, Cao X. A Systematic Review of Promising Strategies of FaithBased Cancer Education and Lifestyle Interventions Among Racial/ Ethnic Minority Groups. J Cancer Educ [Internet]. 2017 Sep; [cited 2017 Dec 27]; 1-15. Available from: https://link.springer.com/article/1 0.1007\%2Fs13187-017-1277-5

25. Sánchez-Vanegas G, Abadía-Barrero CE, De la Hoz F, Nova J, López E. Cáncer de piel: Barreras de acceso e itinerario burocrático. Una experiencia colombiana. Rev Salud Pública [Internet] 2013 Oct; [cited 2017 Dec 27]; 15(5):671-83. Available from: http://www.scielo.org.co/ pdf/rsap/v15n5/v15n5a04.pdf

26. Rodrigues FSS, Polidori MM. Enfrentamento e Resiliência de Pacientes em Tratamento Quimioterápico e seus Familiares. Rev Bras Cancero [Internet]. 2012; [cited 2017 Dec 27]; 58(4):619-27. Available from: http://www.inca.gov.br/rbc/n_58/v04/pdf/07-artigo-enfrentamentoresiliencia-pacientes-tratamento-quimioterapico-familiares.pdf

27. Cunha FF, Vasconcelos EV, Silva SED, Freitas KO. Representações de pacientes oncológicos sobre o tratamento de quimioterapia antineoplásica. Rev Fund Care Online [Internet]. 2017 Jul/Sep; [cited 2017 Dec 27]; 9(3):840-7. Available from: http://www.seer.unirio.br/ index.php/cuidadofundamental/article/view/5579 